\section{Examining genetic susceptibility in acute exacerbations of COPD}

\author{
Emily S Wan ${ }^{1,2}$
}

Acute exacerbations (AE) contribute significantly to morbidity and mortality, and account for a substantial proportion of the direct costs associated with chronic obstructive pulmonary disease (COPD). ${ }^{1}$ Although AE frequency generally increases with worsening spirometric airflow obstruction on the population level, considerable variation in the number of exacerbations experienced by individuals exists. Epidemiological studies support the existence of an 'intrinsic susceptibility' towards $\mathrm{AE}$ which is independent of the degree of impairment in forced expiratory volume in $1 \mathrm{~s}\left(\mathrm{FEV}_{1}\right)$ on spirometry. ${ }^{2}$ This has fuelled the search for genetic variants which may contribute to differential susceptibility towards AEs.

An overview of studies investigating associations between genetic sequence variants and AE risk in COPD is shown in table 1 . The vast majority of studies published to date have used the 'candidate gene' approach, whereby a limited number of variants in genes felt to be plausible contributors to exacerbation susceptibility are examined. Unfortunately, the body of knowledge arising from these investigations is often inconsistent. Non-replication or conflicting reports of association between studies are common, even when identical variants are interrogated (as exemplified by studies on the adrenoreceptor beta 2 gene, $A R D B 2$ ). This is likely due, at least in part, to chance findings, limited power from small study sizes and inadequate statistical rigour. Recent advances in genotyping, computing power and statistical methodologies have facilitated the widespread application of 'hypothesis-free' genomics-based studies of complex diseases and traits, yet studies of $\mathrm{AE}$ risk in COPD using this approach have been conspicuously absent from the literature.

A major limitation of hypothesis-free approaches, which exhaustively

\footnotetext{
${ }^{1}$ Department of Medicine, Brigham and Women's Hospital, Boston, Massachusetts, USA

${ }^{2}$ Department of Medicine, VA Boston Health Care System Jamaica Plain Campus, Boston, Massachusetts, USA
}

Correspondence to Dr Emily SWan, Channing Division of Network Medicine, Department of Medicine, Brigham and Women's Hospital, Boston, MA 02115 6195, USA; emily.wan@channing.harvard.edu interrogate all the variants within a search space regardless of a priori assumptions regarding involvement, is the prerequisite for a well-defined phenotype. AEs of COPD, which are notoriously difficult and labour-intensive to characterise, do not meet this requirement. The diagnosis of an $\mathrm{AE}$ is fundamentally based on a patient's subjective perception of worsening symptoms. There are currently no established biomarkers or gold standards to confirm or disprove the diagnosis of an AE. As shown in table 1 , significant variability in the diagnostic instruments (ie, diary cards, self-report and medical records) and ascertainment methods (retrospective vs prospective) used to define and quantify AEs in different studies exists. Although research in the field has generally moved towards a medical utilization-based consensus definition for AEs, the use of standardised diagnostic codes and/or medical records may still be limited by inaccurate coding or diagnostic uncertainty on the part of the healthcare provider caring for the patient. Thus, the lack of well-curated data on AEs in cohorts large enough to overcome the multiple testing burden inherent to genomics-based studies has limited the application of these methods in identifying genetic loci associated with AE risk.

Not surprisingly, the majority of our knowledge on the association between variants in the mannose-binding lectin 2 $(M B L 2)$ gene and $\mathrm{AE}$ risk derives from candidate gene studies. Given the central role of acute infections in precipitating AEs, the discovery of functional genetic variants in $M B L 2$ which impact systemic levels of MBL, a protein involved in innate immunity, ${ }^{3}$ logically led to interest in the gene as a susceptibility locus. Analogous to studies of $A D R B 2$, the results of candidate gene-based studies of $M B L 2$ variants have been inconsistent. Early studies reported that genetic variants associated with MBL deficiency were correlated with increased exacerbation risk. ${ }^{4-6}$ Subsequently, several larger studies investigating systemic MBL protein levels (but not genotype directly) found no association with exacerbation risk. $^{78}$ Adding to the fray, Dicker et $a l^{9}$ report genetic variants associated with MBL deficiency demonstrate a significant protective effect against AE of COPD.
How should we weigh the findings reported by Dicker et $a l^{9}$ against the existing literature on the association between $M B L 2$ variants and $\mathrm{AE}$ risk? The current study, which includes data from 1796 patients with spirometrically confirmed COPD, is considerably larger than previous genetic studies of MBL2 variants. The use of records-based approaches to identify and quantify AEs over a median follow-up period of 5.4 years in a single-payer medical system with minimal missing data is also considerably more rigorous than methods employed in previous studies. These strengths, combined with the use of statistical models which adjust for relevant covariates such as baseline lung function, comorbidities, and socioeconomic differences, lend credence to a finding which outright contradicts the existing literature on the topic-the counterintuitive link between genetic MBL deficiency with reduced exacerbation risk. The authors then proceed to support the validity of their epidemiological findings through the inclusion of functional and microbiome studies which explore the possible biological underpinnings of the association.

The prevailing theory that increased circulating levels of MBL protein, which is involved in the phagocytosis of pathogens and apoptotic cells, should be associated with protection from AE fails to consider potential differences in MBL function attributable to the local environment of the lungs. Increased oxidative stress in the airways has been postulated to contribute to enhanced generation of oxidised MBL (ox-MBL), a protein which impairs phagocytosis of selected pathogens below control levels. ${ }^{3}$ Thus, higher levels of circulating MBL in 'sufficient' states would lead to increased levels of ox-MBL and paradoxically result in reduced clearance and increased colonisation of the airways by selected pathogens. Dicker et $a l^{9}$ demonstrate that MBL protein selectively binds to (and presumably compromises clearance of) Haemophilus sp in vitro and that individuals with 'sufficient' genotypes have reduced bacterial diversity in induced sputum with an increased prevalence of colonisation with Haemophilus $\mathrm{sp}$. It is notable, however, that the authors did not directly assess whether differential binding of bacteria by MBL2 genotype exists as only one (presumably wild type) recombinant MBL protein was examined. Several of the genetic sequence variants used to characterise deficiency states are missense mutations located in exonic regions which, in addition to impacting quantitative levels of MBL protein, may 
Table 1 Genetic variants investigated for association with AE of COPD

\begin{tabular}{|c|c|c|c|c|c|}
\hline Gene & $\mathrm{N}$ & Variant(s) & Phenotype* & Study & Comments \\
\hline$A C E$ & $206 t$ & rs4646994 & Hospitalisation records & Mlak et al ${ }^{10}$ & Deletion variant protective among males \\
\hline$A D R B 2$ & 5125 & $\begin{array}{l}\text { rs1042713 } \\
\text { rs1042714 }\end{array}$ & $\begin{array}{l}\text { Prospective moderate-to-severe AE (steroids/ } \\
\text { antibiotic treatment) }\end{array}$ & Rabe et $a l^{11}$ & $\begin{array}{l}\text { Pharmacogenetic study; Major allele of } \\
\text { rs1042713 associated with decreased risk of } \\
\text { AE in salmeterol-treated group }\end{array}$ \\
\hline$A D R B 2$ & $190 \dagger$ & $\begin{array}{l}\text { rs1042713 } \\
\text { rs1042714 }\end{array}$ & $\begin{array}{l}\text { 'Frequent' exacerbators ( } \geq 3 \text { hospitalisations } \\
\text { within } 1 \text { year) vs 'Stable' ( } 0 \text { in } 2 \text { years) }\end{array}$ & Vacca et $a l^{12}$ & No association reported \\
\hline$A D R B 2$ & 92 & $\begin{array}{l}\text { rs1042713 } \\
\text { rs1042714 }\end{array}$ & $\begin{array}{l}\text { Self-reported exacerbations during the } \\
12 \text { months prior to enrolment }\end{array}$ & Emeryk-Mksymiuk et al ${ }^{13}$ & $\begin{array}{l}\text { Major allele of rs } 1042713 \text { associated with } \\
\text { increased risk of } A E\end{array}$ \\
\hline EPHX1 & 219 & $\begin{array}{l}\text { rs1051740 } \\
\text { rs2234922 }\end{array}$ & $\begin{array}{l}\text { Moderate-to-severe AE for } 1 \text { year with } \\
\text { administration of oral } N \text {-acetylcysteine }\end{array}$ & Zhang et $a l^{14}$ & $\begin{array}{l}\text { Pharmacogenetic study; 'slow' enzyme } \\
\text { activity group with lower exacerbation rate } \\
\text { than 'fast activity' group }\end{array}$ \\
\hline$F 2 R$ & $203+$ & rs2227744 & $\begin{array}{l}\text { Diary card exacerbations- dichotomised } \\
\text { 'frequent' }(\geq 3) \text { vs 'infrequent' }(<3)\end{array}$ & Platé et $a l^{15}$ & $\begin{array}{l}\text { Minor allele protective for frequent } \\
\text { exacerbations }\end{array}$ \\
\hline GC & $135 t$ & $\begin{array}{l}\text { rs4588 } \\
\text { rs7041 }\end{array}$ & Diary card exacerbations (count) & $\mid s h i i$ et $\left.a\right|^{16}$ & $\begin{array}{l}\text { rs } 4588 \text { variants associated with increased } \\
\text { frequency of exacerbations }\end{array}$ \\
\hline HMOX1 & 368 & $\begin{array}{l}\text { Long }(>32) \text { dinucleotide } \\
\text { repeats }\end{array}$ & $\begin{array}{l}\text { Moderate-to-severe } A E \text { for } 1 \text { year with } \\
\text { administration of oral } N \text {-acetylcysteine }\end{array}$ & Zhang et al ${ }^{17}$ & $\begin{array}{l}\text { Pharmacogenetic study; absence of long } \\
\text { dinucleotide repeats protective }\end{array}$ \\
\hline$M B L 2$ & $200 t$ & rs1800450 & $\begin{array}{l}\text { Hospital admissions by medical record } \\
\text { review+telephone confirmation }\end{array}$ & Yang et $a l^{6}$ & $\begin{array}{l}\text { Minor allele associated with lower systemic } \\
\text { MBL levels and increased risk for AE }\end{array}$ \\
\hline$M B L 2$ & 215 & $\begin{array}{l}\text { rs11003125 } \\
\text { rs7096206 } \\
\text { rs5030737 } \\
\text { rs1800450 } \\
\text { rs1800451 }\end{array}$ & $\begin{array}{l}\text { Moderate-to-severe AEs assessed by } \\
\text { interview+record review for } 3 \text { years following } \\
\text { enrolment. 'Recurrent' vs 'less frequent' }\end{array}$ & Lin et $a l^{4}$ & $\begin{array}{l}\text { Decreased serum MBL levels and increased } \\
\text { proportion of MBL2 deficiency haplotypes } \\
\text { among 'recurrent' exacerbators }\end{array}$ \\
\hline$M B L 2$ & 277 & $\begin{array}{l}\text { rs11003125 } \\
\text { rs7096206 } \\
\text { rs7095891 } \\
\text { rs5030737 } \\
\text { rs1800450 } \\
\text { rs1800451 }\end{array}$ & $\begin{array}{l}\text { Moderate-to-severe AEs by interview, medical } \\
\text { records and public registry data. 'Frequent' }(\geq 2 \text { I } \\
\text { year) vs 'infrequent' ( }<2 / \text { year) }\end{array}$ & Mandal et $a l^{5}$ & $\begin{array}{l}\text { MBL2 deficiency haplotypes more common } \\
\text { in 'frequent' exacerbators, however, no } \\
\text { correlation with systemic MBL levels and } \\
\text { exacerbation phenotypes }\end{array}$ \\
\hline NR3C1 & $207 \dagger$ & $\begin{array}{l}\text { rs56149945 } \\
\text { rs41423247 } \\
\text { rs6189 } \\
\text { rs6190 }\end{array}$ & 'Unstable' ( $\geq 3$ hospitalisations) vs 'stable' & Schwabe et $a l^{18}$ & No association reported \\
\hline SIGLEC9 & 135 & $\begin{array}{l}\text { rs2075803 } \\
\text { rs2258983 }\end{array}$ & Diary card exacerbations (count) & $\mid s h i i$ et $\left.a\right|^{19}$ & $\begin{array}{l}\text { Minor allele of rs } 2075803 \text { associated with } \\
\text { increased risk of AE. Did not replicate in } \\
\text { larger study }\end{array}$ \\
\hline SIGLEC14 & 135 & Null allele & $\begin{array}{l}\text { Prospective interviews - mild to severe AEs } \\
\text { recorded }\end{array}$ & Angata et $a l^{20}$ & $\begin{array}{l}\text { Null allele associated with decreased risk } \\
\text { of } A E\end{array}$ \\
\hline SERPINA1 & $204 \dagger$ & $11478 \mathrm{G} \rightarrow \mathrm{A}$ & $\begin{array}{l}\text { Diary card exacerbations-dichotomised } \\
\text { 'frequent' }(\geq 3) \text { vs 'infrequent' }(<3)\end{array}$ & Quint et $\left.a\right|^{21}$ & No association reported \\
\hline SFTPB & 389 & $\begin{array}{l}\text { rs2118177 } \\
\text { rs2304566 } \\
\text { rs1130866 } \\
\text { rs3024791 }\end{array}$ & Emergency room visits and hospitalisations & Foreman et $a l^{22}$ & $\begin{array}{l}\text { SFTPB variants associated with AE. Variants } \\
\text { in EPHX1, GSTP1, TGFB1, SERPINE2 also } \\
\text { examined but demonstrated no associations }\end{array}$ \\
\hline SFTPD & $192 \dagger$ & $\begin{array}{l}\text { rs911887 } \\
\text { rs2243639 } \\
\text { rs10887199 } \\
\text { rs2255601 } \\
\text { rs721917 } \\
\text { rs726288 }\end{array}$ & $\begin{array}{l}\text { Emergency room visits and hospitalisations- } \\
\text { dichotomised 'high' }(\geq 2) \text { vs 'low' }(<2)\end{array}$ & Ou et $a l^{23}$ & No association with haplotypes reported \\
\hline$T N F$ & $60 t$ & rs1800629 & $\begin{array}{l}\text { Retrospective moderate-to-severe } \mathrm{AE} \text { year prior } \\
\text { to enrolment }\end{array}$ & Özdoğan et al ${ }^{24}$ & No association reported \\
\hline
\end{tabular}

${ }^{*}$ As published in methods section of manuscripts.

†Among studies which enrolled both COPD and controls, only number of COPD subjects included in exacerbation analysis are included in this table.

$A E$, acute exacerbation; COPD, chronic obstructive pulmonary disease; $M B L$, mannose-binding lectin.

contribute to qualitative differences in function which should be assessed.

A careful assessment of the remaining limitations of the study by Dicker et $a l^{9}$ is necessary to contextualise the findings. As noted by the authors, the COPD subjects included in Dicker et al ${ }^{9}$ had relatively mild airflow limitation (mean
$\mathrm{FEV}_{1} 78.0 \%-79.6 \%$ predicted) relative to subjects enrolled in most COPD genetic studies. In addition, the subgroup enrolled in the microbiome analysis of induced 
sputum was modest, with a significant minority $(29.8 \%)$ unable to provide any samples for analysis; this, in addition to consideration of local patterns of bacterial colonisation as well as potential differences in the microbiome of individuals with more advanced COPD should be examined in future studies. Finally, the current study was presumably conducted among an ethnically isolated subpopulation of European descent (Scotland) and replication in an independent cohort was not attempted. The impact of ancestry and population structure on these findings, as well as assessing whether the associations between $M B L 2$ variants and AE risk are generalisable to non-European populations, represent potential future avenues of investigation.

There is a growing misconception that candidate gene studies are irrelevant in the age of genomics. The study by Dicker et $a l^{9}$ serves as an elegant argument against this by demonstrating that data from a well-designed candidate gene study can serve as one component of multiple, converging data streams which collectively support the association between MBL2 variants and $\mathrm{AE}$ susceptibility. It should also be noted that many of the most robust associations reported from genomic studies (eg, the association between TGFB2 and COPD disease status) were originally identified through candidate gene studies. Carefully conducted candidate gene studies will likely remain among the armamentarium of techniques used by researchers to explore the biology of complex disorders. However, due to the relative ease of conducting candidate gene studies, the literature will likely continue to be populated by reports of varying rigour; it will remain the collective responsibility of the scientific community to interpret and adjudicate the findings of such studies.

Funding This study is funded by US Department of Veterans Affairs, Rehabilitation Research \& Development Service (grant no: IK2RX002165).
Competing interests None declared.

Provenance and peer review Commissioned; externally peer reviewed.

(C) Article author(s) (or their employer(s) unless otherwise stated in the text of the article) 2018. All rights reserved. No commercial use is permitted unless otherwise expressly granted.

\section{Check for updates}

To cite Wan ES. Thorax 2018;73:507-509.

Published Online First 9 January 2018

\section{CLinked}

- http://dx.doi.org/10.1136/thoraxjnl-2016-209931

Thorax 2018;73:507-509.

doi:10.1136/thoraxjnl-2017-211106

\section{REFERENCES}

1 Punekar YS, Shukla A, Müllerova H. COPD management costs according to the frequency of COPD exacerbations in UK primary care. Int J Chron Obstruct Pulmon Dis 2014;9:65-73.

2 Hurst JR, Vestbo J, Anzueto A, et al. Susceptibility to exacerbation in chronic obstructive pulmonary disease. N Engl J Med 2010;363:1128-38.

3 Tran HB, Ahern J, Hodge G, et al. Oxidative stress decreases functional airway mannose binding lectin in COPD. PLoS One 2014;9:e98571.

4 Lin CL, Siu LK, Lin JC, et al. Mannose-binding lectin gene polymorphism contributes to recurrence of infective exacerbation in patients with COPD. Chest 2011;139:43-51.

5 Mandal J, Malla B, Steffensen R, et al. Mannosebinding lectin protein and its association to clinical outcomes in COPD: a longitudinal study. Respir Res 2015;16:150.

6 Yang IA, Seeney SL, Wolter JM, et al. Mannose-binding lectin gene polymorphism predicts hospital admissions for COPD infections. Genes Immun 2003;4:269-74.

7 Albert RK, Connett J, Curtis JL, et al. Mannose-binding lectin deficiency and acute exacerbations of chronic obstructive pulmonary disease. Int I Chron Obstruct Pulmon Dis 2012;7:767-77.

8 Eagan TM, Aukrust P, Bakke PS, et al. Systemic mannose-binding lectin is not associated with Chronic Obstructive Pulmonary Disease. Respir Med 2010;104:283-90

9 Dicker AJ, Crichton ML, Cassidy AJ, et al. Genetic mannose binding lectin deficiency is associated with airway microbiota diversity and reduced exacerbation frequency in COPD. Thorax 2018;73:510-8.

10 Mlak R, Homa-Mlak I, Powrózek T, et al. Impact of I/D polymorphism of ACE gene on risk of development and course of chronic obstructive pulmonary disease. Arch Med Sci 2016;12:279-87.

11 Rabe KF, Fabbri LM, Israel E, et al. Effect of ADRB2 polymorphisms on the efficacy of salmeterol and tiotropium in preventing COPD exacerbations: a prespecified substudy of the POET-COPD trial. Lancet Respir Med 2014;2:44-53.

12 Vacca G, Schwabe K, Dück R, et al. Polymorphisms of the beta 2 adrenoreceptor gene in chronic obstructive pulmonary disease. Ther Adv Respir Dis 2009:3:3-10.

13 Emeryk-Maksymiuk J, Emeryk A, Krawczyk P, et al. Beta-2-adrenoreceptor polymorphism at position 16 determines the clinical severity of chronic obstructive pulmonary disease. Pulm Pharmacol Ther 2017:43:1-5.

14 Zhang JQ, Zhang JQ, Liu H, et al. Effect of $\mathrm{N}$-acetylcysteine in COPD patients with different microsomal epoxide hydrolase genotypes. Int J Chron Obstruct Pulmon Dis 2015;10:917-23.

15 Platé M, Lawson PJ, Hill MR, et al. Impact of a functional polymorphism in the PAR-1 gene promoter in COPD and COPD exacerbations. Am J Physiol Lung Cell Mol Physiol 2014;307:L311-16.

16 Ishii T, Motegi T, Kamio K, et al. Association of group component genetic variations in COPD and COPD exacerbation in a Japanese population. Respirology 2014;19:590-5

17 Zhang JQ, Zhang JQ, Fang LZ, et al. Effect of oral $\mathrm{N}$-acetylcysteine on COPD patients with microsatellite polymorphism in the heme oxygenase-1 gene promoter. Drug Des Devel Ther 2015;9:6379-87

18 Schwabe K, Vacca G, Dück R, et al. Glucocorticoid receptor gene polymorphisms and potential association to chronic obstructive pulmonary disease susceptibility and severity. Eur J Med Res 2009;14(Suppl 4):210-5

19 Ishii T, Angata T, Wan ES, et al. Influence of SIGLEC9 polymorphisms on COPD phenotypes including exacerbation frequency. Respirology 2017;22:684-90.

20 Angata T, Ishii T, Motegi T, et al. Loss of Siglec-14 reduces the risk of chronic obstructive pulmonary disease exacerbation. Cell Mol Life Sci 2013;70:3199-210.

21 Quint JK, Donaldson GC, Kumari M, et al. SERPINA1 $11478 \mathrm{G} \rightarrow$ A variant, serum $\alpha 1$-antitrypsin, exacerbation frequency and FEV1 decline in COPD. Thorax 2011;66:418-24.

22 Foreman MG, DeMeo DL, Hersh CP, et al. Polymorphic variation in surfactant protein $B$ is associated with COPD exacerbations. Eur Respir J 2008:32:938-44.

$23 \mathrm{Ou} C Y$, Chen CZ, Hsiue TR, et al. Genetic variants of pulmonary SP-D predict disease outcome of COPD in a Chinese population. Respirology 2015;20:296-303.

24 Özdoğan N, Tutar N, Demir R, et al. Is TNF-? gene polymorphism related to pulmonary functions and prognosis as determined by FEV1, BMI, COPD exacerbation and hospitalization in patients with smoking-related COPD in a Turkish population? Rev Port Pneumol 2014;20:305-10. 